\title{
Locomotion, Feeding, Grooming and the Behavioural Responses to Gravity, Light and Hydrostatic Pressure in the Stage I Zoea Larvae of Ebalia tuberosa (Crustacea: Decapoda: Leucosiidae)
}

\author{
P.J.Schembri * \\ University Marine Biological Station; Millport, Isle of Cumbrae KA28 OEG, Scotland
}

\begin{abstract}
The stage I zoeae of Ebalia tuberosa swam by sculling with the exopodites of the 1 st and 2 nd maxillipeds and flexed the abdomen to brake or change direction. The larvae gained depth by stopping all natatory movements and sinking passively at rates of $\sim 6 \mathrm{~mm} \mathrm{~s}^{-1}$. The zoeae refused both living and dead nauplii of Artemia spp., as well as two species of diatoms, but fed readily on detritic material on the bottom which they scooped up using the endopodites of the maxillipeds and pressed against the mouthparts using the telson. The setae on the posterior border of the telson were used for grooming the maxillipeds and the anterior mouthparts. Day-old stage I zoeae were negatively geotactic, positively phototactic and responded to pressure increases by swimming upwards and by high barokinesis. By the third day some larvae had become positively geotactic but were photopositive, and the majority responded to pressure increases as in the dayold larvae. Five-day old larvae were still photopositive but the majority had become positively geotactic and fewer numbers responded to pressure. Seven-day old larvae failed to respond to any of the stimuli used and assumed a predominantly benthic lifestyle. It is suggested that this anomalous behaviour is related to the dispersal of the larvae and to the specialized habitat requirements of the adults while the rather unusual morphology of the larvae is related to their feeding behaviour and semi-benthic lifestyle.
\end{abstract}

\section{Introduction}

Very little is known about the larvae of crabs of the family Leucosiidae. Although this family contains some 40 living genera (Warner, 1977) with over 300 described species, to

\footnotetext{
* Present address: 72 Brared Street, B'Kara, Malta
}

date the larvae of only 12 species have been described (Rice, 1980). Study of the larval biology of leucosiids has been neglected even more. Apart from a passing mention in general works (see below), there have not been any studies published on this topic.

In terms of number of species, Ebalia is the largest genus of the family and consists of small, robust crabs which spend the greater part of their time buried in coarse sediments. The zoeae of Ebalia spp. are unusual in several respects. Unlike all other non-leucosiid crabs, the telson of Ebalia spp. zoeae is not forked but takes the form of a triangular plate. Furthermore, the zoeae of Ebalia spp. show an extreme reduction in carapace armature, there being no dorsal or lateral carapace spines and a very minute rostrum (Rice, 1980). Behaviourally the larvae of Ebalia spp. are also unusual in that they appear to be most abundant near the bottom rather than near the surface, as in most other decapod larvae (Jorgensen, 1923; Russell, 1927; Lebour, 1928 a, b).

As part of a larger study on British species of Ebalia (Schembri, 1980), the biology of the stage I zoeae of Ebalia tuberosa was investigated in an attempt to find functional explanations for the unusual morphological and behavioural features of these larvae.

\section{Material and Methods}

Larval Culture

Berried female Ebalia tuberosa were dredged off Farland Point, Isle of Cumbrae, Scotland from muddy gravel at a depth of $\sim 40 \mathrm{~m}$. In the laboratory the crabs were kept individually in 2.5-1 jars of seawater in a constant tem-

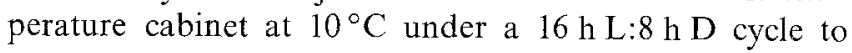
approximate conditions in the field. When larvae hatched they were pipetted off and transferred to larval culture systems. Larvae for use in behavioural experiments were cultured in large $(30 \times 11 \times 24 \mathrm{~cm})$ glass jars containing 21 
of filtered (Whatman $0.3 \mu \mathrm{m}$ ), sterilized seawater of $32 \% \mathrm{~S}$. Larvae were cultured at densities of $\sim 200$ per jar at a constant temperature of $10^{\circ} \mathrm{C}$ under a $16 \mathrm{~h} \mathrm{L:8 \textrm {h } \mathrm { D }}$ cycle. The water was not aerated and was changed every $4 \mathrm{~d}$. No food was given. Larvae for observations on swimming, grooming and feeding behaviour were cultured under similar conditions in $50 \mathrm{~cm}^{3}$ containers at densities of 2-10 larvae per vessel.

For behavioural observations larvae from 11 different batches hatched from 11 different females (1 batch hatched October 1977, 4 batches hatched July 1978, 6 batches hatched July-August 1979) were used. Behavioural responses to gravity, light and pressure were tested in larvae from two separate batches hatched on 19 July 1979 (Batch A) and 2 August 1979 (Batch B). Day old (Day 1), three-day old (Day 3), five-day old (Day 5) and seven-day old (Day 7) larvae from each batch were tested. Larvae older than Day 7 were not tested because after about the sixth day the larvae did not respond to any of the stimuli used.

For observation of feeding, larvae were given (i) oneday old Artemia spp. nauplii; (ii) mixtures of equal parts Dunaliella salina and Phaeodactylum tricornutum; (iii) detritus from the natural substratum of the adults and (iv) no food (controls).

Setae are named according to the nomenclatural scheme proposed by Factor (1978).

\section{Behavioural Observations}

Observations were made on larvae kept in small crystallizing dishes or small aquaria using a travelling stereomicroscope. Observations were also made on larvae in the plankton column and pressure apparatus described below.

\section{Behavioural Responses to Gravity, Light and Pressure}

The plankton column consisted of a $163-\mathrm{cm}$ long 'Perspex' tube (diameter $5 \mathrm{~cm}$ ) closed at one end with a rubber bung. The internal surface of the bung was painted a matt black to prevent reflection of light into the water. The column was marked off in $10-\mathrm{cm}$ lengths and filled to a depth of $150 \mathrm{~cm}$ with filtered seawater. A parallel beam of white light (Thorn B6F, 6V, 48 $\mathrm{W}$ tungsten projector lamp) was directed vertically onto the surface of the water in the column from a rheostat-controlled microscope lightsource. A small crystallizing dish filled with water was placed between the light source and the water surface to act as a heat filter.

The pressure apparatus consisted of a glass pressure vessel of rectangular cross-section $(13 \times 11 \times 28 \mathrm{~cm})$ marked in 4-cm sections and connected to a foot-pump via pressure tubing and pressure-tight gaskets. The pressure vessel was filled to a depth of $12 \mathrm{~cm}$ with filtered seawater. Pressure changes in the vessel were monitored by means of a capillary tube, sealed at one end, and previously calibrated in units of 0.1 Atmospheres (Ats) by manometry. White light (Omega single coil $60 \mathrm{~W}$ pearl tungsten light bulbs) could be directed at the vessel from either side or from above or below.

All experiments were conducted in a darkroom using a dim red light (luminous intensity 0.5 lux) for observation. The seawater had a salinity of $32 \% 0 \mathrm{~S}$ and the temperature was a constant $10^{\circ} \mathrm{C}$.

For gravity and gravity-light experiments, 20 larvae, selected at random from the cultures, were pipetted onto the top of the plankton column and allowed to disperse in darkness for $10 \mathrm{~min}$, after which the number in each $10-\mathrm{cm}$ section was counted. The light, adjusted to a luminous intensity of 140 lux at the water's surface, was switched on and the number of larvae which responded and the direction of the response noted. After 6 min the number of larvae in each section was again counted. The luminous intensity at the water surface was then increased to 1400 lux and the observations repeated. After the second 6-min observation the light was switched off and the response noted. The larvae were discarded after each trial.

For light and pressure experiments 10 larvae were selected at random, placed in the pressure vessel and allowed to disperse in darkness. After 10 min the number of larvae in each section was counted and the pressure increased to $2 \mathrm{Ats}$ and then decreased back to $1 \mathrm{At}$ in 0.1-At steps. Each change lasted for $1 \mathrm{~min}$ (Fig. 4). Half a minute after each pressure change the number of larvae in each section was counted. The larvae were discarded after each trial.

For pressure-light experiments 20 larvae selected at random were tested in batches of 2 or 3 . The larvae were allowed to acclimatize in darkness for $10 \mathrm{~min}$, after which a lamp (luminous intensity $720 \mathrm{lux}$ ) on one side of the pressure vessel was switched on until the larvae had aggregated on the side of the vessel nearest the lamp. An identical lamp on the opposite side was then switched on, at the same time switching off the first lamp. The time taken for each larva to cross from one side to the other was measured using a stopwatch. After $1 \mathrm{~min}$ the second lamp was switched off and the first one switched on and the crossing timed again. Three crossings per larva were timed and the means used to calculate the swimming speed. After a further minute the pressure was increased (or decreased) and the procedure repeated. Ten larvae were tested in an increasing pressure series ( 1 At to 2 Ats in 0.25-At steps) and 10 in a decreasing pressure series ( 2 Ats to 1 At in 0.25-At steps). After each series the larvae were discarded.

\section{Results}

Locomotion

The stage I zoeae of Ebalia tuberosa swam by sculling with the exopodites of the 1st and 2 nd maxillipeds. These were 


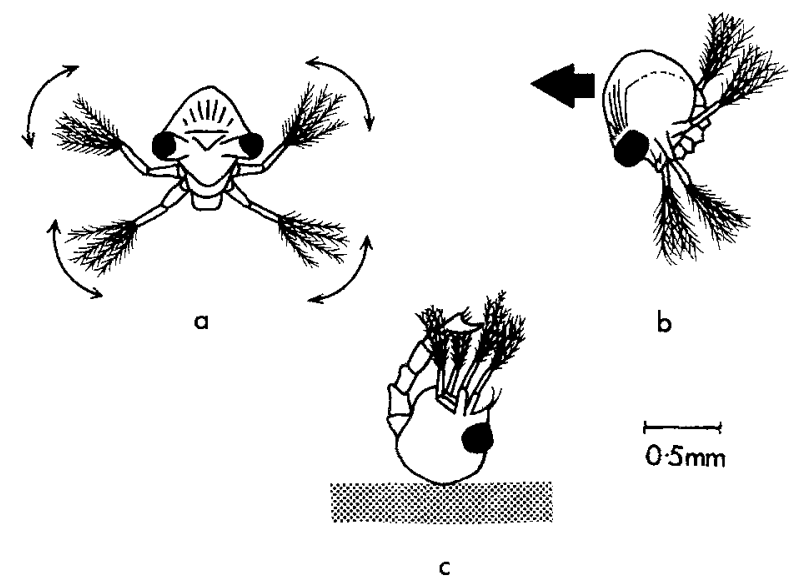

Fig. 1. Ebalia tuberosa. Stage I zoeae (a) 'hovering' in midwater, (b) swimming towards light directed from the side (arrow shows direction of motion) and (c) resting on the bottom. (a) shows a larva in frontal view while (b) and (c) show larvae in lateral view

spread laterally and held at an internal angle of $\sim 75^{\circ}$ to each other (Fig. 1a). Distally, the exopodites bear a fan of 4 long plumose setae which are the main sculling surfaces. When swimming, the abdomen was curled under the cephalothorax and not used for locomotion although it was occasionally flexed when the zoeae braked or changed direction. The dorsal surface of the carapace faced the direction of motion (Fig. 1 b). As soon as the maxillipeds stopped sculling, the zoeae rolled forwards until the dorsal surface of the carapace faced downwards and started sinking.

Sinking was passive although the rate of sinking was controlled by using the exopodites of the maxillipeds as brakes or by gently paddling these appendages. The stage I zoeae have negative buoyancy. When anaesthetized by dropping momentarily into fresh water, individual zoeae placed at the top of the plankton column sunk rapidly and attained speeds of the order of $6 \mathrm{~mm} \mathrm{~s}^{-1}$.
Typical swimming patterns of the stage I zoeae are shown in Fig. 2 a. When close to the water surface the zoeae swam horizontally for short distances, sunk passively for a few $\mathrm{mm}$ and then swam up again and repeated the sequence (Fig. 2 a, trace 1). In midwater the overall pattern was similar with the larvae swimming horizontally and then sinking passively. The original depth level was regained by alternating bouts of upwards swimming and passive sinking (Fig. $2 \mathrm{a}$, trace 2 ). The larvae rested on the bottom with the dorsal surface of the cephalothorax apposed to the substratum and the abdomen spread upwards in the water (Fig. 1 c) and moved in small circles by flexing the abdomen and occasionally by using the maxillipeds. No attempts at burrowing were made when placed on fine silt.

\section{Feeding}

The stage I zoeae ignored freshly hatched Artemia spp. nauplii. They also refused both living and dead nauplii when these were placed on their mouthparts by means of fine needles. When placed in suspensions of Dunaliella salina and Phaeodactylum tricornutum there were no attempts at feeding. Instead the larvae brushed off and rejected any algal cells which adhered to their mouthparts. When given a small amount of sediment, larvae on the bottom of the container vigorously flexed their abdomens until the ventral surface of the cephalothorax was apposed to the substratum. Small fragments of detritus were then picked up by the opposing endopodites of the 1st and 2 nd maxillipeds, which functioned like grabs. The detritus was pressed against the anterior mouthparts by the endopodites and the morphologically ventral surface of the telson. The latter fits exactly under the mouth region. Small fragments were shredded by the combined action of the maxillae and mandibles and ingested. Particles adhering

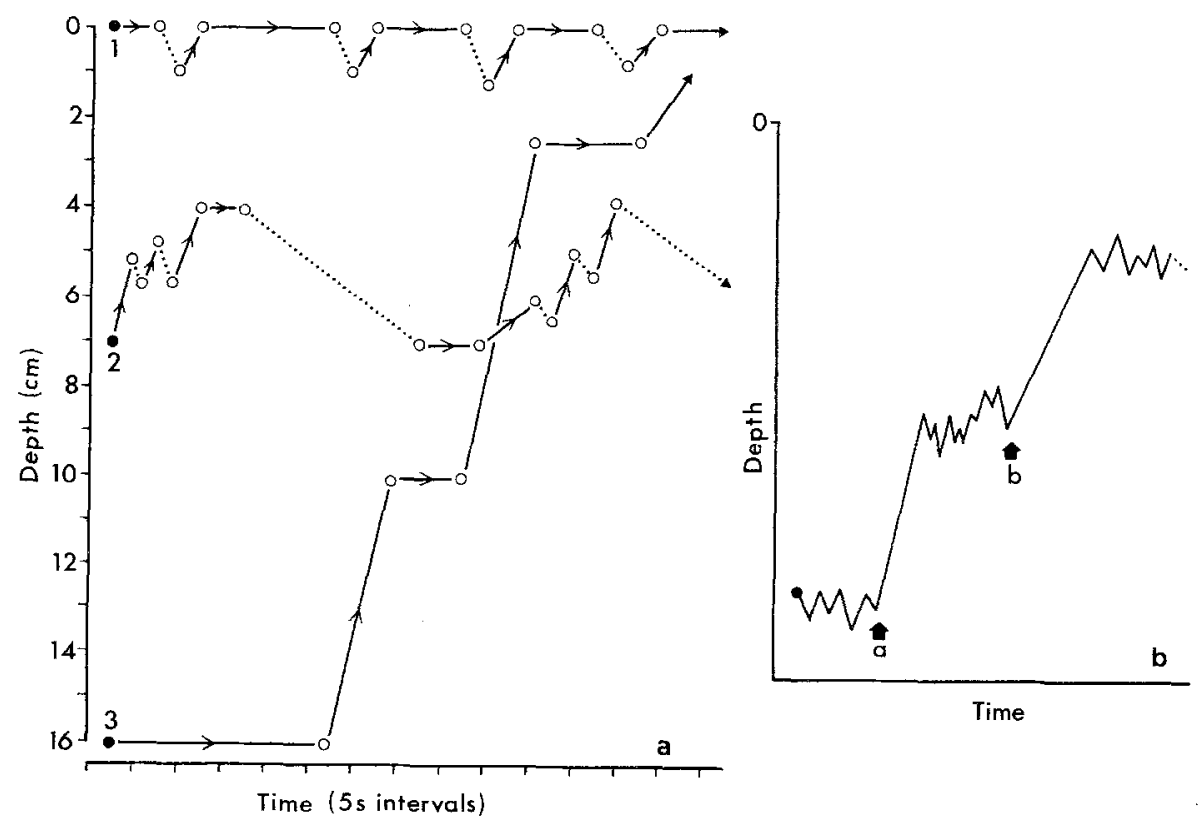

Fig. 2. Ebalia tuberosa. (a) examples of movements of stage I zoeae swimming in a plankton column; trace 1 shows a zoea swimming at the surface; trace 2 shows a zoea swimming in midwater; trace 3 shows a zoea swimming upwards is response to light directed from above; $\bullet$ position of the larvae at the start; $O$, intermediate positions; solid lines represent active swimming; dotted lines represent passive sinking. (b) diagrammatic representation of the movements of stage I zoeae when the intensity of light directed from above is increased (at a) and then increased a second time (at b) 
to the maxillipeds and other mouthparts were brushed off by the setae of the telson (see 'Grooming' below).

\section{Grooming}

The main grooming organ is the telson. The posterior border bears six type Dl serrate setae which, when the abdomen is curled round under the cephalothorax, lie under the mouthparts and point anteriorly. When grooming, both pairs of maxillipeds were flexed forwards under the mouthparts and were then brushed with the telson setae. The telson started each brushing stroke at the base of the maxillipeds and moved anteriorly towards their tips. After several strokes the maxillipeds were again spread laterally and the telson setae were themselves cleaned by being drawn backwards several times over the setae on the maxillae.

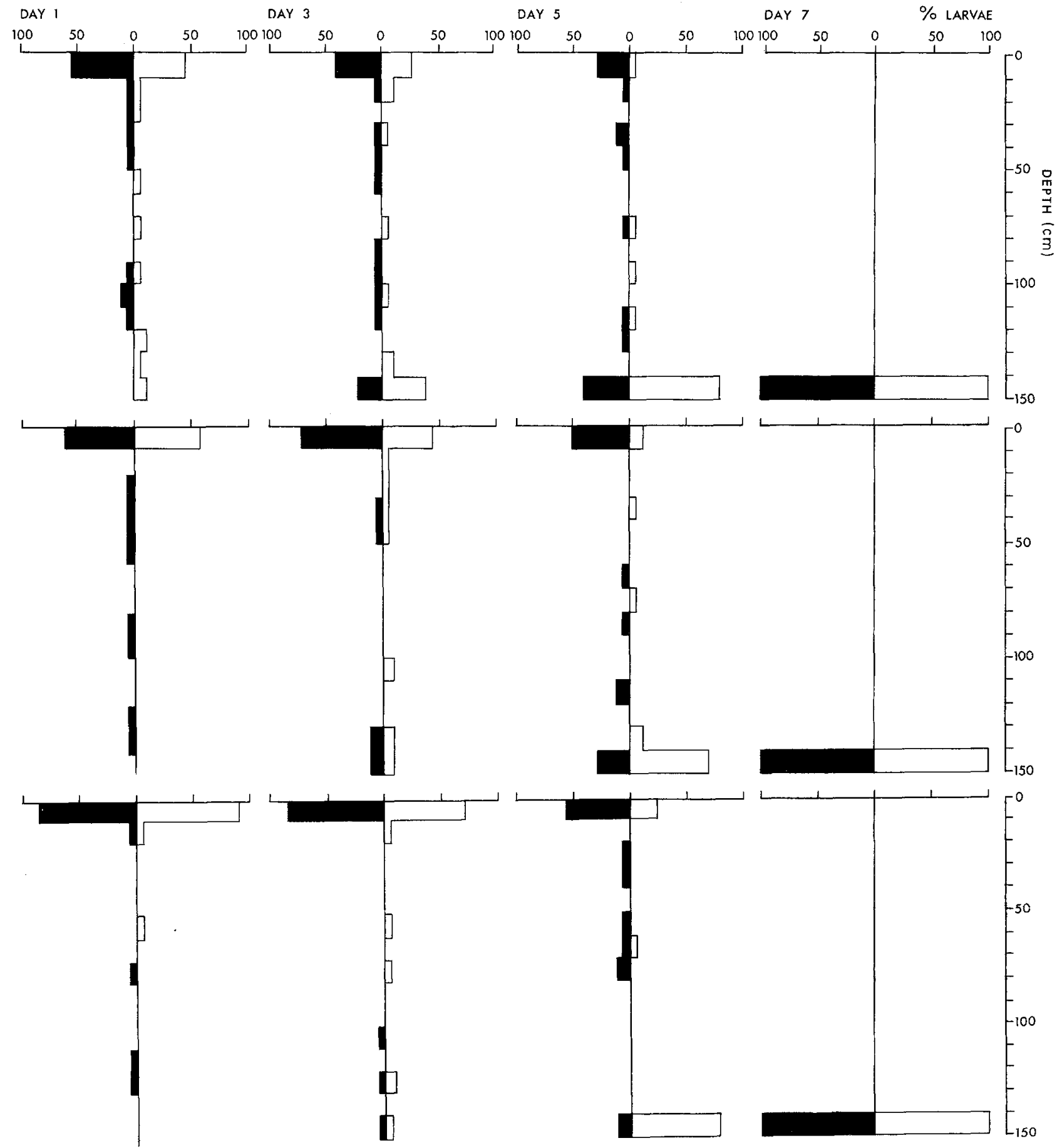

Fig. 3. Ebalia tuberosa. The vertical distribution of stage I zoeae from two batches (solid histograms, Batch A; open histograms, Batch B) expressed as the $\%$ number of larvae in each $10-\mathrm{cm}$ section of a plankton column filled to a depth of $150 \mathrm{~cm}$ with water after (i) 10 min in darkness (upper histograms), (ii) $6 \mathrm{~min}$ in light of luminous intensity 140 lux from above (middle histograms), (iii) $6 \mathrm{~min}$ in light of luminous intensity 1400 lux from above (lower histograms); 20 larvae were used in each case 
Behavioural Responses to Gravity, Light and Hydrostatic Pressure

Gravity. The distribution of the larvae in the plankton column after dispersal in darkness at normal atmospheric pressure is shown in the upper histograms of Fig. 3. The majority of Day-1 larvae from both batches were at the surface with a few in mid-column or near the bottom. As the larvae aged, more tended to settle on the bottom. All Day-7 larvae from both batches were on the bottom. Larvae at the surface and in mid-column showed swimming patterns similar to those shown in Fig. 2 a, traces 1 and 2 .

Light. Responses to light were tested on larvae held in $12 \mathrm{~cm}$ of water only. Hence the effect of gravity was considered to be negligible. Following a short period of acclimatization Day-1, Day-3 and Day-5 larvae from both batches were photopositive and swam towards the light. Day-7 larvae did not respond (Table 1). The mean swimming speeds at normal atmospheric pressure for Day-1, Day- 3 and Day- 5 larvae were compared statistically by one-way analysis of variance (Zar, 1974) and showed no differences for Batch-A larvae $(P \gg 0.25)$ but a significant difference for some Batch-B larvae $(\mathrm{P}<0.01)$. No difference (at $\mathrm{P}=0.05$ ) was found between Batch-B Day-5 and Day-3 swimming speeds, but both were significantly different from the Day-1 swimming speed (Student-Newman-Keuls multiple range test; Zar, 1974).

The orientation of Day-1 larvae relative to the light source was studied by presenting light from above, below or from the side in random sequence. In all cases the larvae swam dorsal surface first towards the light (Fig. 1 b).

Table 1. Ebalia tuberosa. The mean swimming speeds of stage I zoeae from two different batches at specified values of hydrostatic pressure. Figures are means and standard errors $(n=20)$. Sevenday old larvae (Day 7) did not respond. Larvae were swimming towards light directed from the side

\begin{tabular}{|c|c|c|c|c|}
\hline \multirow[t]{2}{*}{$\begin{array}{l}\text { Pressure } \\
\text { (Atmospheres) }\end{array}$} & \multicolumn{4}{|c|}{$\begin{array}{l}\text { Batch A } \\
\text { Mean swimming speed }\left(\mathrm{mm} \mathrm{s}^{-1}\right)\end{array}$} \\
\hline & Day 1 & Day 3 & Day 5 & Day 7 \\
\hline 1.00 & $9.6 \pm 2.8$ & $10.0 \pm 2.5$ & $9.4 \pm 3.8$ & - \\
\hline 1.25 & $9.1 \pm 3.8$ & $10.9 \pm 3.1$ & $10.2 \pm 4.5$ & - \\
\hline 1.50 & $10.1 \pm 3.8$ & $11.1 \pm 3.5$ & $9.7 \pm 2.9$ & - \\
\hline 1.75 & $9.3 \pm 3.5$ & $11.3 \pm 3.6$ & $9.4 \pm 4.3$ & - \\
\hline 2.00 & $9.3 \pm 3.9$ & $10.9 \pm 3.4$ & $10.1 \pm 3.3$ & - \\
\hline \multirow[t]{2}{*}{$\begin{array}{l}\text { Pressure } \\
\text { (Atmospheres) }\end{array}$} & \multicolumn{4}{|c|}{$\begin{array}{l}\text { Batch B } \\
\text { Mean swimming speed }\left(\mathrm{mm} \mathrm{s}^{-1}\right)\end{array}$} \\
\hline & Day 1 & Day 3 & Day 5 & Day 7 \\
\hline 1.00 & $5.8 \pm 2.8$ & $9.1 \pm 3.4$ & $8.1 \pm 3.5$ & - \\
\hline 1.25 & $9.7 \pm 5.3$ & $11.0 \pm 4.1$ & $11.8 \pm 4.9$ & - \\
\hline 1.50 & $11.1 \pm 5.0$ & $14.8 \pm 4.9$ & $13.7 \pm 5.9$ & - \\
\hline 1.75 & $11.6 \pm 3.5$ & $16.0 \pm 4.5$ & $15.5 \pm 4.6$ & - \\
\hline 2.00 & $12.4 \pm 4.6$ & $17.8 \pm 3.3$ & $17.5 \pm 3.6$ & - \\
\hline
\end{tabular}

Table 2. Ebalia tuberosa. The response of stage I zoeae from two different batches to (i) light of luminous intensity 140 lux directed from above after a $10-\mathrm{min}$ accommodation period in darkness; (ii) an increase in luminous intensity to 1400 lux after 6 min; and (iii) switching off the lights after a further $6 \mathrm{~min}$. Figures are the number of larvae at the surface (S) and on the bottom (B) before the stimulus change, and the number which responded; $(+)$ : active swimming towards the light; (-): passive sinking

\begin{tabular}{|c|c|c|c|c|}
\hline & \multicolumn{4}{|l|}{ Batch A } \\
\hline & Day 1 & Day 3 . & Day 5 & Day 7 \\
\hline $140 \operatorname{lux}$ & $\begin{array}{c}11 \mathrm{~S}, 0 \mathrm{~B} \\
9+\end{array}$ & $\begin{array}{l}8 \mathrm{~S}, 2 \mathrm{~B} \\
10+\end{array}$ & $\begin{array}{l}5 \mathrm{~S}, \quad 3 \mathrm{~B} \\
12+\end{array}$ & $\begin{array}{l}\text { OS, } 20 B \\
0\end{array}$ \\
\hline 1400 lux & $\begin{array}{c}12 \mathrm{~S}, 0 \mathrm{~B} \\
6+, 2-\end{array}$ & $\begin{array}{c}14 \mathrm{~S}, 1 \mathrm{~B} \\
5+\end{array}$ & $\begin{array}{l}7 \mathrm{~S}, \quad 1 \mathrm{~B} \\
12+\end{array}$ & $\begin{array}{l}\text { OS, 20B } \\
0\end{array}$ \\
\hline \multirow[t]{3}{*}{ Darkness } & $\begin{array}{l}14 \mathrm{~S}, 0 \mathrm{~B} \\
16-\end{array}$ & $\begin{array}{l}1 \mathrm{~S}, 0 \mathrm{~B} \\
19\end{array}$ & $\begin{array}{l}1 \mathrm{~S}, \quad 1 \mathrm{~B} \\
18-\end{array}$ & $\begin{array}{l}0 \mathrm{~S}, 20 \mathrm{~B} \\
0\end{array}$ \\
\hline & \multicolumn{4}{|l|}{ Batch B } \\
\hline & Day 1 & Day 3 & Day 5 & Day 7 \\
\hline $140 \operatorname{lux}$ & $\begin{array}{l}10 \mathrm{~S}, 0 \mathrm{~B} \\
10+\end{array}$ & $\begin{array}{l}5 \mathrm{~S}, 1 \mathrm{~B} \\
14+\end{array}$ & $\begin{array}{c}1 \mathrm{~S}, 12 \mathrm{~B} \\
7+\end{array}$ & $\begin{array}{l}0 \mathrm{~S}, 20 \mathrm{~B} \\
0\end{array}$ \\
\hline 1400 lux & $\begin{array}{c}11 \mathrm{~S}, 0 \mathrm{~B} \\
9+\end{array}$ & $\begin{array}{c}10 \mathrm{~S}, 1 \mathrm{~B} \\
9+\end{array}$ & $\begin{array}{c}2 \mathrm{~S}, 11 \mathrm{~B} \\
7+\end{array}$ & $\begin{array}{l}0 \mathrm{~S}, 20 \mathrm{~B} \\
0\end{array}$ \\
\hline Darkness & $\begin{array}{l}\mathrm{OS}, 0 \mathrm{~B} \\
20-\end{array}$ & $\begin{array}{l}0 \mathrm{~S}, 0 \mathrm{~B} \\
20-\end{array}$ & $\begin{array}{l}\text { OS, 13B } \\
7-\end{array}$ & $\begin{array}{l}0 \mathrm{~S}, 20 \mathrm{~B} \\
0\end{array}$ \\
\hline
\end{tabular}

Light and Gravity. The responses to light and gravity together were tested on (i) larvae accommodated in darkness for $10 \mathrm{~min}$, then exposed to light of luminous intensity 140 lux from above, and (ii) the same larvae where, after $6 \mathrm{~min}$, the luminous intensity was increased to 1400 lux. In both batches, dark-accommodated Day-1, Day-3 and Day-5 larvae not already at the surface swam rapidly upwards towards the light (Table 2). Progressively lower numbers of Day-3 and Day-5 larvae responded. Day-7 larvae did not respond. The distribution of the larvae after 6-min continuous illumination is shown in the middle histograms of Fig. 3. It is evident that Day-1, Day-3 and Day-5 larvae are dispersed higher in the column relative to the controls (dispersion in darkness, Fig. 3, upper histograms). This higher dispersal is less pronounced in the older larvae.

When the light intensity was increased to 1400 lux, the majority of larvae not already at the surface swam upwards towards the light (Table 2). In one case only did larvae respond to an increase in luminous intensity by sinking (Table 2). Fewer older larvae responded. Day-7 larvae did not respond. The distribution of the larvae after 6 min of continuous illumination at this higher intensity is shown in the lower histograms of Fig. 3. Relative to the controls (dispersion at $140 \mathrm{lux}$, Fig. 3, middle histograms) the larvae were dispersed at a higher level. This was most pronounced for Day-1 larvae and least for Day-5 larvae; Day-7 larvae did not respond. 
The larvae responded to a change in luminous intensity by swimming upwards towards the light (Fig. $2 \mathrm{a}$, trace 3). Some larvae swam to the surface, while others swam to some level higher than their previous position and maintained this new level by alternate upwards swimming and passive sinking (Fig. $2 \mathrm{a}$, trace 2). A further increase in luminous intensity caused larvae maintaining their level in this way to swim upwards and find a new, higher level (Fig. 2b). A decrease in luminous intensity caused the opposite effect. Light-accommodated larvae responded to darkness by stopping all movement and sinking passively (Table 2). Any shadow falling on the larvae or any small decrease in luminous intensity caused the larvae to start sinking before starting to swim again and either regaining their original level or finding a new one, depending on the duration of the intensity decrease.

Hydrostatic Pressure. Because of the shallow depth of water $(12 \mathrm{~cm})$ in the pressure vessel, the effect of gravity was considered to be negligible during these experiments. The distribution of the larvae during increasing and decreasing pressure series is shown in Fig. 4. Larvae from both batches behaved similarly. A decrease in pressure caused an initial cessation of movement and passive sinking in all swimming larvae. An increase in pressure caused an initial upwards swimming in most larvae, including those resting on the bottom. Day- 1 larvae were dispersed high in the water at atmospheric pressure and a progressive increase to $2 \mathrm{Ats}$ did not cause any change. A progressive decrease to ambient caused the larvae to move downwards. Day-3 larvae behaved in a similar manner. An increase to 0.3 Ats above ambient caused Day- 5 larvae from both batches to shift upwards, but following this, further pressure increases up to 1 At above ambient caused more or less even dispersal with perhaps a slight net upwards movement. A progressive decrease in pressure caused a pronounced downwards shift in distribution. Few Day-7 larvae responded to the hydrostatic pressure changes.

Hydrostatic Pressure and Light. The effect of pressure and light together was studied by measuring swimming speed (Table 1). Except for Day-7 larvae, at all pressures, all the larvae responded by actively swimming towards the light. The data in Table 1 were subjected to a two-way analysis of variance (Zar, 1974) to determine the significance of the differences. For Batch $\mathrm{A}$ this analysis showed significant differences $(0.01<\mathrm{P}<0.025)$ between mean swimming
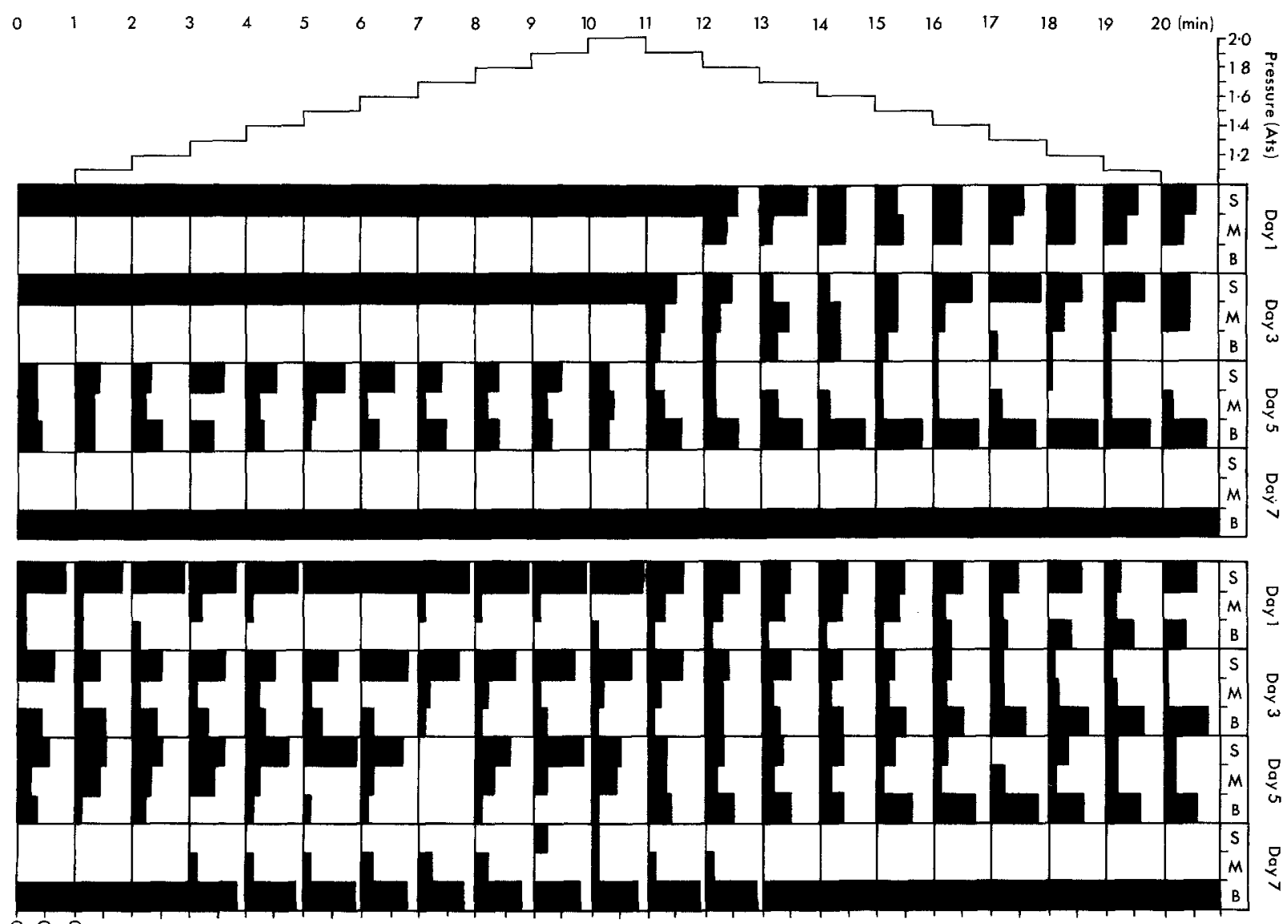

$\circ$ in $8 \%$ LARVAE

Fig. 4. Ebalia tuberosa. The vertical distribution of stage I zoeae from two batches (top, Batch A; bottom, Batch B) expressed as the \% number of larvae in each of three 4-cm sections ( $S$, surface; M, middle; B, bottom) of a pressure vessel filled with $12 \mathrm{~cm}$ of water during increasing and decreasing hydrostatic pressure in darkness; the pressure changes used and their duration are shown by the top graph; 10 larvae were used in each case 
speeds at different ages but pressure, and pressure and age combined, had no significant effect (at $\mathrm{P}=0.05$ ) on mean swimming speed. Day-1 and Day-5 mean swimming speeds are not significantly different (at $\mathrm{P}=0.05$ ) but both are significantly different from the Day-3 mean swimming speed [Student-Newman-Keuls (SNK) multiple range test; Zar, 1974]. Two-way analysis of variance on batch B data showed significant differences $(\mathrm{P}<0.001)$ in swimming speeds between different ages and different pressure treatments, but the two factors combined do not affect the mean swimming speed. Mean swimming speeds for Day-5 and Day-3 larvae are not significantly different (at $\mathrm{P}=0.05$ ), however both differ significantly from that of Day-1 larvae (SNK test). Mean swimming speed increases as the hydrostatic pressure increases. Except for the values at 1.50 Ats and $1.75 \mathrm{Ats}$, the mean swimming speeds differ significantly from each other (at $\mathrm{P}=0.05$; $\mathrm{SNK}$ test).

\section{Discussion}

\section{Behaviour}

Workers who have studied the bathymetric distribution of crab larvae have commented that zoeae of Ebalia spp. occur almost exclusively in bottom samples. Thus Jorgensen (1923) reported zoeae of E. tuberosa to be most abundant near the bottom with fewer individuals in midwater and fewer still near the surface. Russell (1927), Lebour (1928a, b) and Schembri (1982) all reported the larvae of E. tuberosa as staying mainly near the bottom. Lebour (1928 a) observed the behaviour of the stage I zoea of E. tuberosa in the laboratory and described the larvae as first coming to the surface but later descending to the bottom.

The present study confirms these observations; newly hatched prezoeae drop to the bottom and in a short time moult to stage I zoeae which immediately swim to the surface. After the 6 th or 7 th day, the stage I zoeae no longer swim upwards but spend all their time on the bottom. It thus appears that the occasional records of stage I zoeae of Ebalia tuberosa in surface plankton samples may be those newly moulted zoeae still in their 'pelagic' phase. It is not known whether the stage II and subsequent zoeal stages are exclusively benthic or whether they also have a brief pelagic phase. The latter is possible since stage II and later stages have occasionally been found in surface samples (Jorgensen, 1923; Schembri, 1982). Nearly all other brachyurans studied to date have pelagic zoeal stages and it is the megalopa which assumes a benthic habit before metamorphosis into the 1st crab stage. An exception is Cancer irroratus where the settling stage appears to be the stage $V$ zoea (Bigford, 1979).

The stage I zoeae of Ebalia tuberosa swim by sculling with the exopodites of the maxillipeds. This method is universal in brachyuran zoeae (Hyman, 1920; Foxon, 1934; Herrnkind, 1968; Sulkin, 1973; Warner, 1977; Bigford, 1979). Cessation of the natatory movements results in immediate sinking (see also Foxon, 1934; Warner, 1977). E. tuberosa is capable of downwards movement both by passive sinking and active swimming. Downwards swimming was only observed in larvae moving to light experimentally directed from below. Passive sinking appears to be the normal method for downwards movement and is possibly an adaptation to conserve energy.

When swimming, the stage I zoeae of Ebalia tuberosa orientate with the dorsal surface facing the direction of movement, irrespective of the nature and direction of the stimulus causing the response. This orientation appears to be the most common in brachyuran zoeae (Foxon, 1934; Gurney, 1942; Sulkin, 1973, 1975; Warner, 1977; Bigford, 1979), although other, less common, postures have been described (Welsh, 1932; Spooner, 1933; Sulkin, 1975). Foxon (1934) suggested that the spines on the carapace and telson may act as flotation devices. If this is so then their absence in Ebalia spp. zoeae may be related to their predominantly benthic lifestyle, as already suggested by Lebour (1928a). It is interesting to note that zoeae of Pinnotheres pisum, which are thought to lead a benthic existence, also have rudimentary spines on the carapace and telson while those of its cogener $P$. pinnotheres, which are pelagic, have well developed spines (Lebour, 1928a, b).

The food of brachyuran zoeae appears to be mainly small zooplankton although plant material may also be taken (Lebour, 1928b). Herrnkind (1968) described the mechanism of prey capture by zoeae of Uca pugilator. In this species prey is captured by the abdomen, the prey being pinned between the fork of the telson and the rostral spine. The zoeae of Ebalia spp., lacking both a forked telson and a well-developed rostral spine, are clearly illadapted for capturing prey in this way. All attempts to feed the stage I zoeae of E. tuberosa on Artemia spp. nauplii or diatoms failed, although the zoeae fed readily on detritus. The plate-like telson is used to press detritus against the mouthparts and it is far better adapted for this function than for capturing swimming zooplankton in the manner of $U$. pugilator. Lebour (1928 a, b) however, has succeeded in feeding the stage I zoeae of E. tuberosa on Pomatoceros sp. and echinoderm larvae and on the diatom Nitzschia sp., while Ingle (personal communication) has raised the same species from the egg to the juvenile crab stage on a diet of Artemia spp. nauplii. Nonetheless the benthic habit of the zoeae and the morphology of the telson suggest that the main food source of this species is probably detritic material from the bottom although other food may be taken when the preferred food is not available.

Responses to Gravity, Light and Hydrostatic Pressure

With few exceptions, studies on the ontogeny of behavioural patterns in larval brachyurans have only considered changes occurring in different stages. As Bigford (1979) pointed out, larval behaviour may change not only from stage to stage, but also as each particular stage ages. This 
is clearly the case in Ebalia tuberosa. Experiments show that the behaviour of the young stage I zoeae is influenced by at least three interacting factors: gravity, light and pressure. The responses to these factors change as the larvae age, and appear to change at different rates in different individuals. On about the 6 th or 7 th day after moulting there is an abrupt change in behaviour and the larvae assume a benthic lifestyle.

Day-old stage I zoeae of Ebalia tuberosa are negatively geotactic, positively phototactic and respond to an increase in pressure by swimming upwards and in some by increasing the swimming speed, i.e. they exhibit high barokinesis (Fraenkel and Gunn, 1961). These responses complement each other to give a distribution skewed towards the upper portion of the water column. By the 3rd day some larvae are positively geotactic and by the 5 th day this number is higher still. The larvae remain photopositive and the majority respond to an increase in pressure by swimming upwards and in some by high barokinesis. Thus after 1-2 d after moulting, the effect of gravity opposes that of light and pressure in increasing numbers of larvae, and the distribution shifts downwards and progressively skews towards the lower regions of the water column. A decreasing photopositive response and a shift from geonegative to geopositive behaviour with age are common occurrences in brachyuran larvae (Sulkin, 1973; Forward and Costlow, 1974; Castro, 1978; Bigford, 1979; Sulkin et al., 1980). In nearly all, however, these changes occur after or just before the moult from the last zoeal stage to the megalopa and mark the change from a pelagic (zoeal) to a benthic (megalopal) lifestyle. E. tuberosa is highly unusual in that this change occurs during the 1st zoeal stage after only about $7 \mathrm{~d}$ from moulting.

Each individual larva takes up a position in the water column so that the opposing stimuli are in equilibrium. This dynamic interplay of stimuli and responses is clearly demonstrated by altering the intensity of one stimulus while keeping the others constant. Thus when the light intensity was increased, after equilibrium in the plankton column, the larvae swam upwards to a new higher position. When the light was switched off, the larvae sunk in response to the now dominant stimulus of gravity. This particular response may be defensive in that a larva will respond to a shadow falling on it by rapid sinking, hence escaping possible predators. A similar shadow response has been described for the larvae of Rhithropanopeus harrisi by Forward (1976). It is generally held that early stages of benthic invertebrates are found higher up in the water column than later stages (Thorson, 1964; Sandifer, 1973, 1975), and this has been interpreted as a mechanism for dispersal of the larvae by surface currents (Thorson, 1964). In Ebalia tuberosa the stage I zoeae live in the surface plankton for a short time only, hence if the crabs are to use surface currents for dispersal they must possess an efficient mechanism whereby they reach the surface as soon as possible after moulting. The complementary effects of gravity, light and pressure on the early ( $1-2 \mathrm{~d}$ old) zoeae provide such a mechanism.
The responses of the early stage I zoeae of Ebalia tuberosa to light in the laboratory imply that in the field the larvae will respond to diurnal light changes by swimming upwards towards the light during the day and sinking towards the bottom at night. This migratory pattern is opposite that found in the majority of meroplanktonic organisms and has been termed a "reversed migration pattern" by Ott and Forward (1976), who observed it in larvae of the xanthid crab Rhithropanopeus harrisi (see also Forward and Costlow, 1974). The value of this reversed pattern to E. tuberosa may be related to navigation and dispersal and perhaps protection from predators and to the specialized feeding habits of the larvae.

While light is considered to be the principal ecological factor controlling the vertical distribution of planktonic larvae (Thorson, 1964), hydrostatic pressure may also be important, especially when light quality and intensity are variable due to hydrographic, meteorological and seasonal conditions (Rice, 1964). Responses to pressure may serve to compensate for any sudden upward or downward displacement of the larvae in the water, perhaps by eddy currents. The results of the pressure experiments on Day-5 larvae suggest that pressure-cued depth compensation may only operate above a certain critical depth which may vary with the age of the larva. Responses to pressure similar to those reported here for Ebalia tuberosa have been demonstrated in a number of brachyuran larvae and have also been postulated to serve as depth regulatory mechanisms (Hardy and Bainbridge, 1951; Rice, 1964, 1966; Sulkin, 1973, 1975; Bently and Sulkin, 1977; Wheeler and Epifano, 1978).

The patterns of vertical distribution of crab larvae have been shown to be important in determining where these finally settle, particularly if the adults live in 'difficult to get to' habitats, such as estuaries, lagoons (Sandifer, 1973, 1975; Latz and Forward, 1977; Bigford, 1979; Sulkin et al., 1980), and, in the case of parasites or commensals, the host (Castro, 1978). Such is the case of adult Ebalia tuberosa which are substratum specific, this being related to their cryptic habit (Schembri, 1981 b) and to their feeding strategy (Schembri, 1981 a). Initially the larvae are planktonic and probably exploit surface currents for dispersal over a wide area. Later the larvae become semi-benthic, probably to ensure that they find suitable substrata prior to settlement. The reversed migration pattern and other behavioural responses of the larvae then cause them to move up and down in the lower regions of the water column exploiting bottom currents for dispersal and to alternate bouts of swimming with periods on the bottom probably for feeding and bottom-testing. Clearly bottomtesting is very important for a crab such as E. tuberosa, which has well-defined substratum preferences and where the preferred substratum is only found in scattered patches as in the study area (Schembri, 1980). Moreover female E. tuberosa produce few eggs relative to other crabs (Schembri, 1982), and go to great lengths to protect them during the long incubation period (Schembri, 1981c, 
1982). Clearly the behaviour of the larvae is geared to ensure continued survival, efficient dispersal and settlement on the preferred substratum.

Apart from light, gravity and hydrostatic pressure, the behaviour of larval crabs is also influenced by such factors as temperature (Ott and Forward, 1976), salinity (Latz and Forward, 1977), the plane of polarization of light (Via and Forward, 1975; Bardolph and Stavn, 1978) and nutritional state of the larvae (Cronin and Forward, 1980). These and other factors may also be important in Ebalia tuberosa. Starvation did not seem to have any effect on the responses of the stage I zoeae of E. tuberosa. In all three feeding experiments (Artemia spp. nauplii, algae and detritus) and the control, all larvae showed the same behaviour patterns described above. Larvae, however, responded more readily to light if the water was gently agitated than in still water (unpublished data). More studies on the responses of larval E. tuberosa need to be done before the unusual behaviour of this crab is fully understood.

Acknowledgements. I am grateful to Professor J. A. Allen for providing the necessary facilities and for his interest in this work. I thank Dr. R. J. A. Atkinson for the loan of equipment and advice on its use, Dr. M. P. Benwell for advice on statistical analysis and Dr. R. W. Ingle for permission to quote his unpublished work. This work was carried out during the tenure of a Commonwealth Scholarship awarded by the Association of Commonwealth Universities.

\section{Literature Cited}

Bardolph, M. and R. H. Stavn: Polarized light sensitivity in the stage I zoea of the mud crab Panopeus herbstii. Mar. Biol. 46, $327-333$ (1978)

Bentley, E. and S. D. Sulkin: The ontogeny of barokinesis during the zoeal development of the xanthid crab Rhithropanopeus harrisii (Gould). Mar. Behav. Physiol. 4, 275-282 (1977)

Bigford, T. E.: Ontogeny of light and gravity responses in rock crab larvae (Cancer irroratus). Mar. Biol. 52, 69-76 (1979)

Castro, P.: Settlement and habitat selection in the larvae of Echinoecus pentagonus (A. Milne Edwards), a brachyuran crab symbiotic with sea urchins. J. exp. mar. Biol. Ecol. 34, 259-270 (1978)

Cronin, T. W. and R. B. Forward: The effects of starvation on phototaxis and swimming of larvae of the crab Rhithropanopeus harrisii. Biol. Bull. mar. biol. Lab., Woods Hole 158, 283-294 (1980)

Factor, J. R.: Morphology of the mouthparts of larval lobsters, Homarus americanus (Decapoda: Nephropidae), with special emphasis on their setae. Biol. Bull. mar. biol. Lab., Woods Hole 154, 383-408 (1978)

Forward, R. B.: A shadow response in a larval crustacean. Biol. Bull. mar. biol. Lab., Woods Hole 151, 126-140 (1976)

Forward, R. B. and J. D. Costlow: The ontogeny of phototaxis by larvae of the crab Rhithropanopeus harrisii. Mar. Biol. 26, $27-33(1974)$
Foxon, G. E. H.: Notes on the swimming methods and habits of certain crustacean larvae. J. mar. biol. Ass. U.K. 19, 829-849 (1934)

Fraenkel, G. S. and D. L. Gunn: The orientation of animals. Kineses, taxes and compass reactions, $376 \mathrm{pp}$. New York: Dover Publications 1961

Gurney, R.: Larvac of decapod Crustacea, 306 pp. London: Ray Society 1942

Hardy, A. C. and R. Bainbridge: Effect of pressure on the behaviour of decapod larvae (Crustacea). Nature 167, 354-355 (1951)

Herrnkind, W. F.: The breeding of Uca pugilator (Bosc) and mass rearing of the larvae with comments on behaviour of the larval and early crab stages (Brachyura, Ocypodidae). Crustaceana suppl. 2, 214-224 (1968)

Hyman, O. W.: On the development of Gelasimus after hatching. J. Morph. 33, 485-525 (1920)

Jorgensen, O.: Marine plankton. IV. Crustacea. Rep. Dove mar. Lab. n.s. 12, I12-133 (1923)

Latz, M. I. and R. B. Forward: The effect of salinity upon phototaxis and geotaxis in a larval crustacean. Biol. Bull. mar. biol. Lab., Woods Hole 153, 163-179 (1977)

Lebour, M. V.: Studies of the Plymouth Brachyura. II. The larval stages of Ebalia and Pinnotheres. J. mar. biol. Ass. U.K. I5, $109-124(1928 \mathrm{a})$

Lebour, M. V.: The larval stages of the Plymouth Brachyura. Proc. zool. Soc., Lond. 1928, 473-560 (1928 b)

Ott, F. S. and R. B. Forward: The effect of temperature on phototaxis and geotaxis by larvae of the crab Rhithropanopeus harrisi (Gould). J. exp. mar. Biol. Ecol. 23, 97-107 (1976)

Rice, A. L.: Observations on the effects of changes of hydrostatic pressure on the behaviour of some marine animals. J. mar. biol. Ass. U.K. 44, 163-175 (1964)

Rice, A. L.: The orientation of pressure responses of some marine Crustacea. Proc. Symp. Crustacea mar. biol. Ass. India 3, 1124-1131 (1966)

Rice, A. L.: The first zoeal stage of Ebalia nux A Milne Edwards 1883 , with a discussion of the zoeal characters of the Leucosiidae (Crustacea, Decapoda, Brachyura). J. nat. Hist. 14, $331-337$ (1980)

Russell, F. S.: The vertical distribution of marine macroplankton. $V$. The distribution of animals caught in the ring-trawl in the daytime in the Plymouth area. J. mar. biol. Ass. U.K. 14, $557-608$ (1927)

Sandifer, P. A.: Distribution and abundance of decapod larvae in the York River estuary and adjacent lower Chesapeake Bay, Virginia. Chesapeake Sci. 14, 235-257 (1973)

Sandifer, P. A.: The role of pelagic larvae in recruitment of populations of adult decapod crustaceans in the York River estuary and adjacent lower Chesapeake Bay, Virginia. Estuar. coast. mar. Sci. 3, 269-279 (1975)

Schembri, P. J.: Aspects of the biology, behaviour and functional morphology of the crab Ebalia tuberosa (Pennant). $\mathrm{Ph} . \mathrm{D}$. thesis, University of Glasgow, 194 pp (1980)

Schembri, P. J.: Feeding in Ebalia tuberosa (Pennant) (Crustacea: Decapoda: Leucosiidae). J. exp. mar. Biol. Ecol. 55, 1-10 (1981 a)

Schembri, P. J.: Substratum preferences, burrowing and righting in Ebalia tuberosa (Pennant) (Crustacea: Decapoda: Leucosiidae). Mar, Behav. Physiol. 8, 149-161 (1981 b)

Schembri, P. J.: The functional morphology of the branchial chambers and associated structures of Ebalia tuberosa (Crustacea: Decapoda: Leucosiidae), with special reference to ventilation of the egg-mass. J. Zool., Lond. 195, 423-436 (1981c)

Schembri, P. J.: The biology of a population of Ebalia tuberosa (Crustacea: Decapoda: Leucosiidae) from the Clyde Sea area. J. mar. biol. Ass. U.K. 62, 101-115 (1982)

Spooner, G. M.: Observations on the reactions of marine plankton to light. J. mar. biol. Ass. U.K. 19, 385-438 (1933) 
Sulkin, S. D.: Depth regulation of crab larvae in the absence of light. J. exp. mar. Biol. Ecol. 13, 73-82 (1973)

Sulkin, S. D.: The influence of light in the depth regulation of crab larvae. Biol. Bull. mar. biol. Lab., Woods Hole 148, 333-343 (1975)

Sulkin, S. D., W. Van Heukelem, P. Kelly and L. Van Heukelem: The behavioral basis of larval recruitment in the crab Callinectes sapidus Rathbun: a laboratory investigation of ontogenetic changes in geotaxis and barokinesis. Biol. Bull. mar. biol. Lab., Woods Hole 159, 402-417 (1980)

Thorson, G.: Light as an ecological factor in the dispersal and settlement of larvae of marine bottom invertebrates. Ophelia I, 167-208 (1964)

Via, S. E. and R. B. Forward: The ontogeny and spectral sensitivity of polarotaxis in larvae of the crab Rhithropanopeus harrisii (Gould). Biol. Bull. mar. biol. Lab., Woods Hole 149, $151-266(1975)$
Warner, G. F.: The biology of crabs, 202 pp. London: Elek Science 1977

Welsh, J. H.: Temperature and light as factors influencing the rate of swimming of the mussel crab Pinnotheres maculatus Say. Biol. Bull. mar. biol. Lab., Woods Hole 63, 310-326 (1932)

Wheeler, D. E. and C. E. Epifano: Behavioral response to hydrostatic pressure in larvae of two species of xanthid crabs. Mar. Biol. 46, 167-174 (1978)

Zar, J. H.: Biostatistical analysis, 620 pp. New Jersey: Prentice Hall Inc. 1974

Date of final manuscript acceptance: October 26, 1982.

Communicated by O. Kinne, Hamburg 